\title{
CEPHALOMETRIC CHARACTERIZATION OF SKELETAL CLASS II, DIVISION 1 MALOCCLUSION IN WHITE BRAZILIAN SUBJECTS*
}

\author{
CARACTERIZAÇÃO CEFALOMÉTRICA DA MÁ OCLUSÃO DE CLASSE II, $1^{a}$. DIVISÃO, \\ EM BRASILEIROS LEUCODERMAS
}

\begin{abstract}
Marcos Roberto de FREITAS ${ }^{1}$, Marcos Antonio Cirino dos SANTOS ${ }^{2}$, Karina Maria Salvatore de FREITAS ${ }^{3}$ Guilherme JANSON ${ }^{4}$, Daniel Salvatore de FREITAS ${ }^{5}$, José Fernando Castanha HENRIQUES ${ }^{1}$
\end{abstract}

\author{
1- DDS, MSc, PhD, Full Professor. Department of Orthodontics. Bauru Dental School, University of São Paulo, Brazil. \\ 2- DDS, MSc, Orthodontic Graduate Student (Master degree). Department of Orthodontics. Bauru Dental School, \\ University of São Paulo, Brazil. \\ 3- DDS, MSc, PhD, Orthodontic Graduate Student (Doctor Degree). Department of Orthodontics. Bauru Dental School, \\ University of São Paulo, Brazil. \\ 4- DDS, MSc, PhD, Associate Professor. Department of Orthodontics. Bauru Dental School, University of São Paulo, Brazil. \\ 5- DDS, Graduate Student. Bauru Dental School, University of São Paulo, Brazil. \\ * This paper is based on research by Dr Marcos Antonio Cirino dos Santos in partial fulfillment of the requirements for the degree of Master of \\ Science in Orthodontics at Bauru Dental School, University of São Paulo.
}

Corresponding address: Dr. Marcos Roberto de Freitas - Al. Octávio Pinheiro Brisolla, 9-75 - Cep.: 17012-901 Bauru - SP

Phone: (14) 3235-8333 - Fax: (14) 32341961 - e-mail: bst00111@uol.com.br

Received: November 18, 2004 - Modification: February 28, 2005 - Accepted: March 3, 2005

\begin{abstract}
O ne of the main points in Orthodontic studies is the growth and development of the craniofacial structures. In this study, skeletal cephalometric characteristics of Class II, division 1 malocclusion were assessed in lateral cephalograms. The experimental sample comprised 55 white Brazilian individuals of both genders, with an ANB angle of 4.5 degrees or higher. The mean age of the subjects was 13.5 years. Steiner and McNamara Jr cephalometric analyses were used in order to evaluate the relation between angular and linear positions of the apical bases, the dental and cranial structures, comparing with the values obtained in the control group (available at Bauru Dental School-USP). The results showed that, for the experimental group, the maxilla was well positioned in relation to the cranial base. The maxillomandibular relation showed an increased overjet, which was predictable based on criteria for sample selection. The geometrical proportion of the apical bases presented a small mandible and a normal sized maxilla. The craniofacial growth pattern presented a vertical tendency. The maxillary incisors were buccally inclined and well positioned by the linear evaluation. The mandibular incisors showed marked buccal inclination and protrusion. No statistically significant difference between genders was found.

Uniterms: Cephalometrics; Malocclusion, Angle Class II ; Skeletal malocclusion.
\end{abstract}

\section{RESUMO}

$U_{\mathrm{m}}$ dos principais temas em Ortodontia é o estudo do crescimento e desenvolvimento craniofacial. Neste estudo, a caracterização cefalométrica da Classe II, $1^{\text {a }}$ divisão, esquelética, foi estudada em telerradiografias em norma lateral. O grupo experimental foi composto por 55 indivíduos brasileiros leucodermas, de ambos os gêneros, apresentando um ângulo ANB maior ou igual a 4.5 graus. A idade média foi 13.5 anos. Foram utilizadas grandezas cefalométricas da análise de Steiner e McNamara Jr. para avaliar a relação entre as posições angulares e lineares das bases apicais, estruturas dentárias e destas com as estruturas cranianas, comparando com os valores obtidos de um grupo controle (disponível na Faculdade de Odontologia de Bauru-USP). Os resultados mostraram que, no grupo experimental, a maxila apresentou-se bem posicionada em relação à base craniana. A relação maxilomandibular apresentou uma sobressaliência acentuada, o que já era previsível dado o critério de seleção da amostra experimental. A proporção geométrica entre as bases apicais apresentou a mandíbula de tamanho pequeno e a maxila normal. O padrão de crescimento craniofacial apresentou uma tendência vertical. Os incisivos superiores apresentaramse inclinados para vestibular e bem posicionados pela avaliação linear. Os incisivos inferiores mostraram-se acentuadamente inclinados para vestibular e protruídos. Não houve diferença estatisticamente significante entre os gêneros.

Unitermos: Cefalometria; Maloclusão de Angle Classe II; Má oclusão esquelética. 


\section{INTRODUCTION}

The Class II malocclusion is characterized as skeletal when there is involvement of the jaws, and dental when there is just a dentoalveolar involvement; however, a combination of skeletal and dental factors happens in most cases $^{12,22}$. This malocclusion can be related to a retrognathic mandible, prognathic maxilla, or a combination of both ${ }^{12,22}$.

The Class II division 1 malocclusion is the most frequent in particular clinics ${ }^{25}$, caused, in most times, by a retrognathic mandible ${ }^{1,6,12}$. The Class II malocclusions have a strong hereditary component as etiologic factor, both in families and in ethnic and racial groups ${ }^{16}$. The ethnic aspect in an important characteristic in the morphologic variation of malocclusions ${ }^{16}$.

The complex etiology and great variety of morphologic and functional aspects of this malocclusion motivate some studies ${ }^{18,23,22}$, aiming at obtaining a more accurate diagnosis and to allow appropriate and compatible treatment for the different types of Class II division 1 malocclusion ${ }^{18}$.

Although many studies have investigated Class II malocclusion characteristics ${ }^{3,4,12,14,21}$, few have studied the characteristics of skeletal Class II malocclusions in specific ethnic groups ${ }^{1,16}$. Therefore, in order to provide more specific information regarding this type of malocclusion in white Brazilian subjects, this comparative cephalometric study was undertaken.

\section{Statement of the problem}

The objective of this study is the cephalometric characterization of skeletal Class II, division 1 malocclusion in white Brazilian individuals with a mean age of 13.5 years

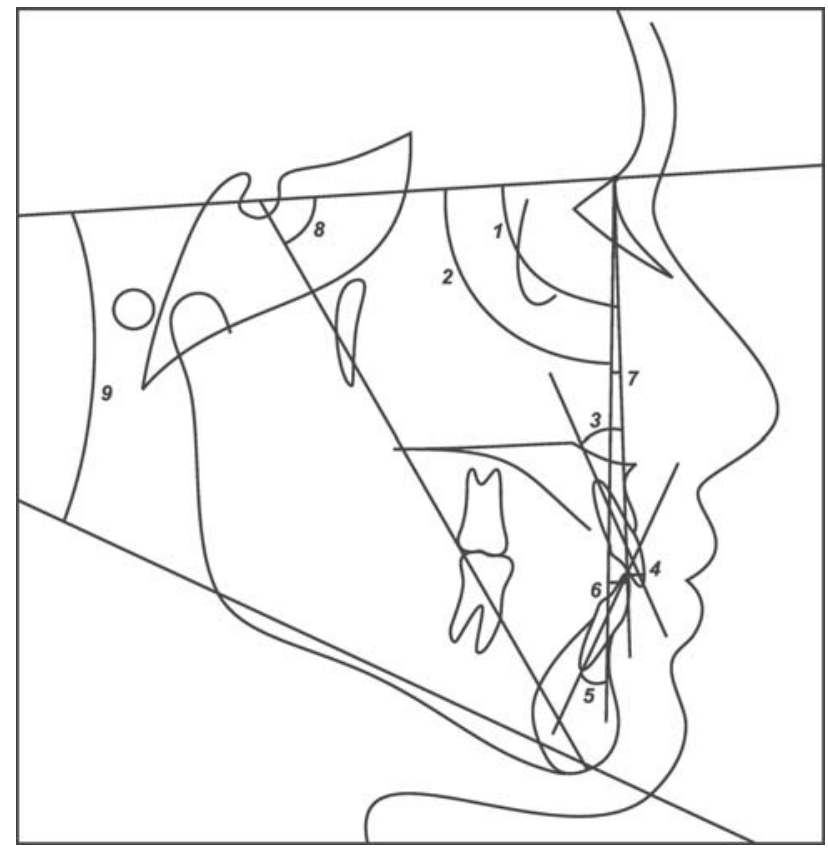

FIGURE 1- Cephalometric measurements used: 1-SNA (degree); 2-SNB (degree); 3-1.NA (degree); 4-1-NA (mm); 5-1.NB (degree); 6-1-NB (mm); 7-ANB (degree); 8- NS.Gn (degree); 9-SN.GoGn (degree) that had not been previously submitted to any orthodontic treatment. The experimental group (Class II) was compared to normative cephalometric values obtained of 2 thesis studying normal occlusions at the Discipline of Orthodontics at Bauru Dental School ${ }^{9,11}$ (control group).

Evaluation of the following characteristics of the jaws was made: angular and linear sagittal relation between maxilla and mandible, and related to the cranial base; geometric proportion between maxilla and mandible; craniofacial growth pattern and position of maxillary and mandibular incisors; presence of differences between genders.

\section{MATERIAL}

The experimental sample comprised 55 lateral cephalograms of white Brazilian individuals of both genders (22 women and 33 men), with a mean age of 13.5 years. This sample was originated from the records of a private clinic.

The criteria used for inclusion of subjects in the experimental sample were: full cusp molar Class II relation, Class II division 1 cases without previous orthodontic treatment, ANB angle equal or larger than 4.5 degrees.

The control group comprised subjects with the same age (13.5 years), presenting normal occlusion, and data on these subjects were obtained from 2 thesis of the Discipline of Orthodontics at Bauru Dental School ${ }^{9,11}$.

\section{METHODS}

The lateral cephalograms used were taken according to the conventional norms. Each cephalogram was digitized and measured by the software Cef-X version 2.1.31. After registering all data, the cephalometric points of interest were

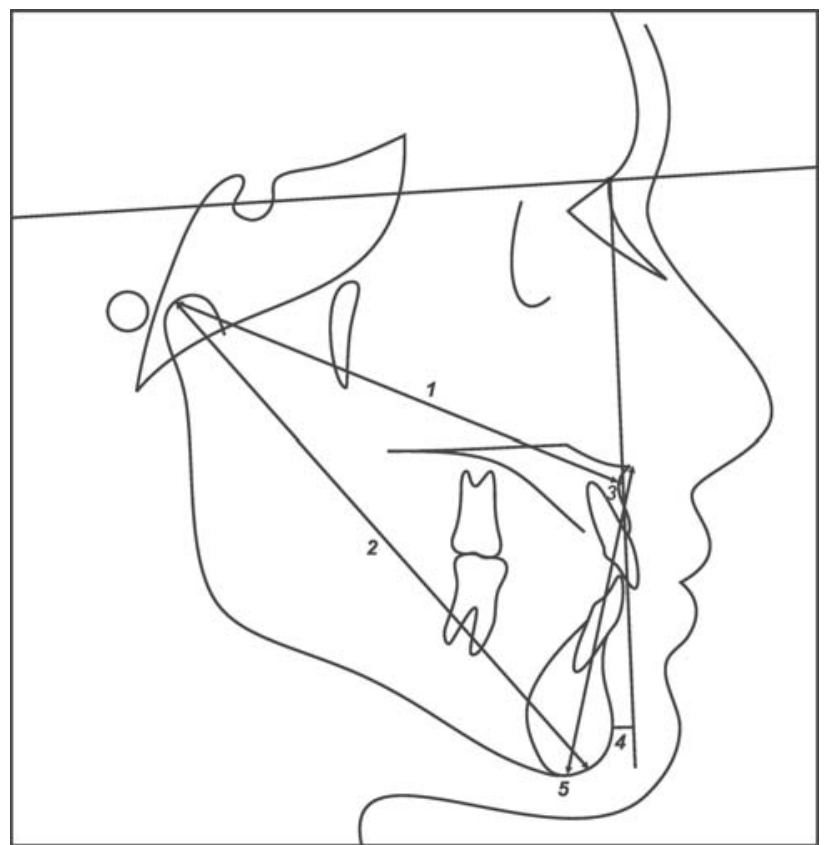

FIGURE 2- Cephalometric measurements used (in $\mathrm{mm}$ ): 1-Co-A; 2-Co-Gn; 3-A-NPerp; 4-P-NPerp; 5- ENA-Me. 
delineated, and measurements were supplied by the software. The magnification level of the lateral cephalograms was $6 \%$, and it was corrected by the software.

Cephalometric data of the Steiner ${ }^{24}$ and McNamara $\mathrm{Jr}^{13}$ analyses were used. The angular and linear measurements of dental and skeletal structures used are presented in Figures 1 and 2. The normal values (control group) for measurements SNA (degrees), SNB (degrees), ANB (degrees), SN.GoGn (degrees), NS.Gn (degrees), 1.NA (degrees), 1-NA (mm), 1.NB (degrees) and 1-NB (mm) were obtained from the study of Martins ${ }^{11}$, and for the measurements A-Nperp (mm), P-Nperp (mm), Co-A (mm), Co-Gn (mm), MMD (maxillomandibular difference subtraction of the values of Co-Gn and Co-A, in millimeters) and ENA-Me (mm), obtained from the study of Janson ${ }^{9}$.

\section{Error study}

Within a week interval from the first measurement, fourteen randomly selected radiographs were retraced, redigitized, and re-measured by the same examiner. The casual error was calculated according to Dahlberg's formula ${ }^{7}$ $\left(\mathrm{Se}^{2}=\sum \mathrm{d}^{2} / 2 \mathrm{n}\right)$, and the systematic error with dependent $t$ tests, for $\mathrm{p}<0.05$.

\section{Statistical analysis}

The means and standard deviations for the data were calculated. The experimental group was compared with the control group ${ }^{9,11}$ using the Student t test. The comparison between genders in the experimental group used the same statistical test. Statistically significant values were considered if $\mathrm{p}<0.05$.

\section{RESULTS}

The data presented in Table 1 presents the casual and systematic errors for the studied measurements. No systematic errors were detected, and the random errors varied from 0.002 degrees for SNB to 1.04mm for 1-NA.

Comparison between genders showed that only the ANB angle presented statistically significant difference (Table 2). Table 3 presents comparison data between the experimental and control groups ${ }^{9,11}$.

\section{DISCUSSION}

In the experimental group, there was no statistically significant difference between genders. This finding is in agreement with the literature, which has stated that gender exerts little or no effect on skeletal and dental components in Class II malocclusions ${ }^{18}$.

The sagittal position of the maxilla (SNA) was similar to the control group, with a well positioned maxilla in relation to the cranial base, corroborating previous studies ${ }^{6,8,12,15,17}$. However, the linear sagittal position of the maxilla (A-NPerp) showed moderate protrusion. Interpretation of this result should be cautious, because the last measurement is linear (in millimeters), and the difference between maxilla and mandible should be considered. These diverging results between angular and linear measurements for the maxilla can be partly explained by the difficulty in the location of the reference points of the Frankfort plane. Another point could be the inclination of the oclusal plane, interfering with the results. It should remembered that the control group belonged to two theses, and each of the measurements cited was compared to a different control group, although both of normal occlusion. The effective length of the maxilla (CoA) was similar to the control group, presenting a normal

TABLE 1- Casual and systematic errors for the studied measurements

\begin{tabular}{|c|c|c|c|c|c|c|c|}
\hline \multirow[t]{2}{*}{ Measurements } & \multicolumn{2}{|c|}{ 1st. Measurement } & \multicolumn{2}{|c|}{ 2nd. Measurement } & \multirow[t]{2}{*}{ Dahlberg } & \multirow[t]{2}{*}{$\mathbf{t}$} & \multirow[t]{2}{*}{$\mathbf{P}$} \\
\hline & Mean & SD & Mean & SD & & & \\
\hline SNA (degree) & 81.97 & 3.48 & 81.98 & 3.51 & 0.53 & 0.078 & 0.938 \\
\hline SNB (degree) & 75.39 & 3.23 & 75.39 & 3.18 & 0.38 & 0.002 & 0.998 \\
\hline ANB (degree) & 6.58 & 1.56 & 6.59 & 1.53 & 0.41 & 0.109 & 0.913 \\
\hline A-Nperp (mm) & 2.36 & 3.33 & 2.4 & 3.47 & 0.73 & 0.299 & 0.766 \\
\hline P-Nperp (mm) & -6.35 & 5.9 & -6.5 & 6.4 & 1.09 & 0.703 & 0.485 \\
\hline Co-A (mm) & 92.15 & 4.62 & 92.15 & 4.39 & 0.91 & 0.006 & 0.995 \\
\hline Co-Gn (mm) & 113.7 & 6.28 & 113.62 & 6.02 & 0.78 & 0.483 & 0.631 \\
\hline MMD (mm) & 21.55 & 4.40 & 21.47 & 4.22 & 0.75 & 0.499 & 0.620 \\
\hline ENA-Me (mm) & 68.83 & 5.21 & 68.76 & 5.23 & 0.45 & 0.879 & 0.383 \\
\hline NS.Gn (degree) & 70.21 & 3.11 & 70.31 & 3.18 & 0.59 & 0.906 & 0.369 \\
\hline SN.GoGn (degree) & 34.51 & 5.18 & 34.57 & 5.1 & 0.52 & 0.669 & 0.506 \\
\hline 1.NA (degree) & 25.45 & 7.91 & 25.31 & 7.64 & 1.45 & 0.490 & 0.626 \\
\hline 1-NA (mm) & 5.3 & 3.11 & 5.13 & 3.16 & 0.87 & 1.042 & 0.302 \\
\hline 1.NB (degree) & 29 & 6.97 & 28.96 & 6.41 & 1.21 & 0.168 & 0.867 \\
\hline 1-NB (mm) & 6.68 & 2.65 & 6.69 & 2.66 & 0.21 & 0.422 & 0.675 \\
\hline
\end{tabular}


sized maxilla ${ }^{6,12,15}$.

These characteristics found for the maxilla, well positioned and with normal size, have a direct implication in the Class II treatment ${ }^{20}$. The literature has been giving emphasis in these therapeutic aspects, which are scientific findings that subsidize functional orthopedics ${ }^{10,20}$. Th e sagittal position of the mandible (SNB) presented it retracted in relation to the cranial base. The effective length (Co-Gn) showed a small sized mandible. These results are in agreement with the literature ${ }^{6,12,15,17,23,22}$, demonstrating that the mandible presents great participation in this type of malocclusion. There are relevant studies ${ }^{12,14,19}$ that accept the variations in the position of the mandible as inherent characteristics of this type of malocclusion. These cephalometric results justify the mandibular advancement for correction of the Class II malocclusion in great part of the cases $^{10,20}$.

The sagittal discrepancy of the apical bases (ANB) presented statistically significant difference when compared to the control group. The process of craniofacial growth

TABLE 2- Comparison between genders (experimental group) by the Student t test

\begin{tabular}{|c|c|c|c|c|c|}
\hline \multirow[t]{2}{*}{ Measurements } & \multicolumn{2}{|c|}{ Males $(\mathrm{N}=33)$} & \multicolumn{2}{|c|}{ Females (N=22) } & \multirow[b]{2}{*}{$\mathbf{P}$} \\
\hline & $X$ & SD & 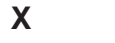 & SD & \\
\hline SNA (degree) & 81.41 & 3.71 & 82.82 & 2.99 & 0.145 \\
\hline SNB (degree) & 75.23 & 3.55 & 75.63 & 2.74 & 0.654 \\
\hline ANB (degree) & 6.19 & 1.30 & 7.18 & 1.75 & $0.018 *$ \\
\hline A-Nperp (mm) & 1.93 & 3.64 & 3.00 & 2.74 & 0.244 \\
\hline P-Nperp (mm) & -6.43 & 6.03 & -6.24 & 5.84 & 0.911 \\
\hline Co-A (mm) & 92.41 & 5.25 & 75.63 & 3.53 & 0.654 \\
\hline Co-Gn (mm) & 114.13 & 6.96 & 113.05 & 5.18 & 0.538 \\
\hline MMD (mm) & 21.72 & 3.68 & 21.29 & 5.39 & 0.729 \\
\hline ENA-Me (mm) & 68.76 & 5.03 & 68.95 & 5.59 & 0.896 \\
\hline NS.Gn (degree) & 70.30 & 3.24 & 70.08 & 2.99 & 0.801 \\
\hline SN.GoGn (degree) & 34.61 & 5.29 & 34.35 & 5.12 & 0.861 \\
\hline 1.NA (degree) & 25.81 & 7.87 & 24.89 & 8.11 & 0.676 \\
\hline 1-NA (mm) & 5.45 & 3.18 & 5.07 & 3.06 & 0.657 \\
\hline 1.NB (degree) & 75.23 & 3.55 & 75.63 & 7.55 & 0.654 \\
\hline 1-NB (mm) & 6.24 & 2.37 & 7.33 & 2.95 & 0.137 \\
\hline
\end{tabular}

* STATISTICALLY SIGNIFICANT FOR P<0.05.

TABLE 3- Means, standard deviations and comparison between experimental and control group by the Student $t$ test

\begin{tabular}{llllllll}
\hline & \multicolumn{2}{c}{ Experimental group } & & \multicolumn{3}{c}{ Control group } \\
Measurements & $\mathbf{X}$ & SD & $\mathbf{N}$ & $\mathbf{X}$ & $\mathbf{S D}$ & $\mathbf{N}$ & $\mathbf{P}$ \\
\hline SNA (degree) & 81.97 & 3.48 & 55 & 81.49 & 3.15 & 85 & 0.39 \\
SNB (degree) & 75.39 & 3.23 & 55 & 79.41 & 2.92 & 85 & $0.00^{*}$ \\
ANB (degree) & 6.58 & 1.56 & 55 & 2.06 & 1.87 & 85 & $0.00^{*}$ \\
A-Nperp (mm) & 2.36 & 3.33 & 55 & 0.58 & 3.03 & 60 & $0.00^{*}$ \\
P-Nperp (mm) & -6.35 & 5.90 & 55 & -2.98 & 5.64 & 60 & $0.00^{*}$ \\
Co-A (mm) & 92.15 & 4.62 & 55 & 91.62 & 4.33 & 60 & 0.52 \\
Co-Gn (mm) & 113.70 & 6.28 & 55 & 119.36 & 6.39 & 60 & $0.00^{*}$ \\
DMM (mm) & 21.55 & 4.40 & 55 & 27.75 & 4.30 & 60 & $0.00^{*}$ \\
ENA-Me (mm) & 68.83 & 5.21 & 55 & 67.18 & 5.03 & 60 & 0.08 \\
NS.Gn (degree) & 70.21 & 3.11 & 55 & 66.32 & 3.23 & 85 & $0.00^{*}$ \\
SN.GoGn (degree) & 34.51 & 5.18 & 55 & 31.47 & 4.56 & 85 & $0.00^{*}$ \\
1.NA (degree) & 25.45 & 7.91 & 55 & 23.19 & 5.45 & 85 & $0.04^{*}$ \\
1-NA (mm) & 5.30 & 3.11 & 55 & 5.64 & 1.88 & 85 & 0.42 \\
1.NB (degree) & 29 & 6.97 & 55 & 26.31 & 4.20 & 85 & $0.00^{*}$ \\
1-NB (mm) & 6.68 & 2.65 & 55 & 5.23 & 1.61 & 85 & $0.00^{*}$ \\
\hline
\end{tabular}

* STATISTICALLY SIGNIFICANT FOR P<0.05. 
and development in normal conditions promote a decrease in the ANB angle, by the differential growth between maxilla and mandible, tending to flatten the profile, what would benefit this malocclusion ${ }^{5}$. However, when this malocclusion is analyzed in the absence of treatment, it is verified that the decrease of ANB can be minimum, and even an increase could happen ${ }^{5}$. It is important to emphasize that the Class II malocclusion does not present self-correction, meaning that the probable decrease in the ANB angle only happens with treatment $^{2,1}$.

The difference between maxilla and mandible (DMM) was statistically significant when compared to the control group. In normal subjects with the same age of the sample studied, an increase in this measure is expected ${ }^{3,12}$. The results confirm the great discrepancy of dimensional and postural relations observed between the apical bases.

The craniofacial growth pattern presented a vertical tendency. These findings are uniform to those mentioned in most studies $3,6,12,14-16$, however some authors found contrasting results ${ }^{5,18}$.

The lower anterior facial height (ENA-Me) behaved in a similar way as the control group, although it was slightly increased in the experimental group. The excessive vertical development of the craniofacial component is a consequence of the decrease in the posterior facial height and increase in the lower anterior facial height ${ }^{12,15}$. The behavior of the lower anterior facial height similar to the control group suggested an increase in the posterior facial height in the experimental group.

The maxillary incisors presented buccal inclination (1.NA). That finding is in consonance with the results of previous studies $6,8,12,19$. The maxillary incisors are reference for identification of the division of the Class II malocclusion. Martins ${ }^{11}$, when comparing a normal occlusion group to Steiner's norms ${ }^{24}$, noted great differences and concluded that theses norms ${ }^{24}$ are not reliable for application in white Brazilian individuals. The linear position (1-NA) showed well-positioned maxillary incisors in relation to the cranial base. This result diverges from most studies in the literature ${ }^{6,8,12,19}$, but it can be due to the control group used for comparison ${ }^{11}$, which presented protruded maxillary incisors in Brazilian subjects with normal occlusion, when compared to the Steiner's norms ${ }^{24}$.

The angular measurement for the mandibular incisors (1.NB) presented statistically significant difference, showing mandibular incisors strongly buccally inclined. Previous studies showed minimum alteration of these teeth, with a buccal tendency ${ }^{6,12}$. The results for the linear position of mandibular incisors (1-NB) showed protrusion in relation to their apical base, indicating tooth compensation for the skeletal discrepancy.

The definition of Class II, division 1 malocclusion is based on the sagittal relation between the apical bases and their teeth, but not exclusively sagittal; the vertical and traverse involvement should also be considered. Therefore, diagnosis and treatment prognosis should be based on sagittal, vertical and traverse relations, to verify the level of dental compensation in Class II, division 1 malocclusions.

\section{CONCLUSIONS}

According to the methodology used, the cephalometric characterization of white Brazilian subjects presenting Class II, division 1 malocclusion (experimental group) was the following:

1 - The maxilla was well positioned in relation to the cranial base.

2 - The mandible was retracted in relation to the cranial base.

3 - The relationship between maxilla and mandible showed an increased overjet.

4 - The geometric proportion between the apical bases presented a small mandible and a normal size maxilla.

5 - The craniofacial growth pattern showed a vertical tendency.

6 - The maxillary incisors were buccally inclined and well positioned in relation to the apical base.

7 - The mandibular incisors were strongly buccally inclined and protruded in relation to the apical base.

8 - There was no statistically significant difference between genders.

\section{REFERENCES}

1- Bishara SE, Jakobsen JR, Vorhies B, Bayati P. Changes in dentofacial structures in untreated Class II division 1 and normal subjects: a longitudinal study. Angle Orthod. 1997;67(1):55-66.

2- Bishara SE. Mandibular changes in persons with untreated and treated Class II division 1 malocclusion. Am J Orthod Dentofacial Orthop. 1998;113(6):661-73.

3- Björk A. Facial growth in man, studied with the aid of mettalic implants. Acta Odont Scand. 1955;13:8-34.

4- Brodie AG. On growth pattern of the human headfrom the third months to the eight years of life. Am J Anat. 1941;68:209-62.

5- Buschang PH, Tanguay R, Turkewicz J, Demirjian A, La Palme L. A polynomial approach to craniofacial growth: description and comparison of adolescent males with normal occlusion and those with untreated Class II malocclusion. Am J Orthod Dentofacial Orthop. 1986;90(5):437-42.

6- Carter NE. Dentofacial changes in untreated Class II division 1 subjects. Br J Orthod 1987;14(4):225-34.

7- Dahlberg G. Statistical methods for medical and biological students. New York: Interscience; 1940.

8- Feldmann I, Lundstrom F, Peck S. Occlusal changes from adolescence to adulthood in untreated patients with Class II Division 1 deepbite malocclusion. Angle Orthod. 1999;69(1):33-8.

9- Janson GRP. Estudo longitudinal e comparativo do crescimento facial - dos 13 a 18 anos de idade - em jovens brasileiros leucodermas, utilizando a analise cefalometrica de Mcnamara Junior. Bauru; 1990. [Tese (Doutorado) - Faculdade de Odontologia de Bauru da Universidade de São Paulo]

10- Johnston JR. LE. Functional appliances: a mortgage on mandibular position. Aust Orthod J. 1996;14(3):154-7. 
11- Martins DR. Estudo comparativo dos valores cefalometricos das analises de Downs, Tweed, Steiner e Alabama, com os leucodermas, de origem mediterranea.. Bauru; 1979. [Tese -Doutorado - Faculdade de Odontologia de Bauru da Universidade de São Paulo].

12- McNamara Jr JA. Components of class II malocclusion in children 8-10 years of age. Angle Orthod. 1981;51(3):177-202.

13- McNamara Jr JA. A method of cephalometric evaluation. Am J Orthod. 1984;86(6):269-300.

14- Moyers RE, Riolo ML, Guire KE, Wainright RL, Bookstein FL. Differential diagnosis of class II malocclusions. Part 1. Facial types associated with class II malocclusions. Am J Orthod. 1980; 78(5):47794

15- Ngan PW, Byczek E, Scheick J. Longitudinal evaluation of growth changes in Class II division 1 subjects. Semin Orthod. 1997;3(4):22231 .

16- Phelan T, Buschang PH, Behrents RG, Wintergerst AM, Ceen RF, Hernandez A. Variation in Class II malocclusion: comparison of Mexican mestizos and American whites. Am J Orthod Dentofacial Orthop. 2004;125(4):418-25.

17- Riedel RA. The relation of maxillary structures to cranium in malocclusion and in normal occlusion. Angle Orthod. 1952;22(3):1425 .

18- Rothstein T, Yoon-Tarlie C. Dental and facial skeletal characteristics and growth of males and females with class II, division 1 malocclusion between the ages of 10 and 14 (revisited)-part I: characteristics of size, form, and position. Am J Orthod Dentofacial Orthop. 2000;117(3):320-32.

19- Rothstein TL. Facial morphology and growth from 10 to 14 years of age in children presenting Class II, Division 1 Malocclusion: a comparative roentgenographic cephalometric study. Am J Orthod. 1971;60(6):619-20.

20- Rudzki-Janson I, Noachtar R. Functional appliance therapy with the Bionator. Semin Orthod. 1998;4(1):33-45.

21- Sarhan OA, Hashim HA. Dento-skeletal components of class II malocclusions for children with normal and retruded mandibles. J Clin Pediat Dent. 1994;18:99-103.

22- Sassouni V. A classification of skeletal facial types. Am J Orthod. 1969;55(2):109-23.

23- Sassouni V. The Class II syndrome: differential diagnosis and treatment. Angle Orthod. 1970;40(4):334-41.

24- Steiner CC. Cephalometrics for you and me. Am J Orthod. 1953;39:720-55.

25- Weiland FJ, Bantleon HP. Treatment of Class II malocclusions with the Jasper Jumper appliance - a preliminary report. Am J Orthod Dentofacial Orthop. 1995;108(4):341-50. 